\title{
LEGAL STATUS OF FLAT UNIT OWNERSHIP CERTIFICATE (STRATA TITLE) IN INDONESIA
}

\section{Made Herman SUSANTO (i) 1*}

Ibrahim R. (D) 2

1 Udayana University, Faculty of Law, Doctoral Study Program (S3) on Science of Law, made.herman.fh@ gmail.com,

*Correspondent Author

2 Udayana University, Faculty of Law, Study Program (S3) on Science of Law, mrprof.ibrahim@ gmail.com

Article history:
Accepted 29 July 2020
Available online 31 August 2020
Keywords:
Legal Status,
Flat Unit Ownership Certificate,
Legal Research,
Conflict.

\begin{abstract}
A b s t r a c t
This study seeks to examine the legal status of flat unit ownership rights between Law Number 5 of 1960 and Law Number 20 of 2011; by using normative legal research (statute approach and concept approach), this research concludes: the legal status of flat unit ownership certificate as stipulated in the Law Number 5 of 1960 and Law Number 20 of 2011 cannot be said to have a conflict of legal norms. The difference in interpretation of those laws can be resolved by: (1) The principle of lex specialis derogat lex generale, means specific laws (in this case is Law Number 20 of 2011 concerning Flats) overrides general laws (in this case is Law Number 5 of 1960 concerning Basic Agrarian Law); (2) Article 16 paragraph (1) letter h of Law Number 5 of 1960 concerning Basic Agrarian Law provides: other rights not included in the previously mentioned rights will be stipulated in the law, as well as the temporary rights as referred to in article 53; thus, the term flat unit ownership certificate can be accepted because it does not conflict with applicable laws and regulations.
\end{abstract}

\section{Introduction}

Based on Article 17 of Law Number 20 of 2011 concerning Flats, flat can be built on: a. rights of ownership; b. rights to build or utilize on state's land; and c. rights to build or utilize on land with management rights. For land with management rights, the law provides specific arrangements. The developer must clarify the status of the land before selling the flat units. Article 17 of the law states that flat can be built on:

a. Rights of ownership;

b. Rights to build or utilize on state's land;

c. Rights to build or utilize on land with management rights.

Article 18 provides that in addition to being built on land categories as mentioned in Article 17, public and/or special flats can also be built with:

a. The utilization of state's/regional property in form of land; b. The utilization of waqf (endowment) land.

Article 19 paragraph (1) concerning the utilization of state's/regional property in the form of land for the construction of flat as referred to in Article 18 letter a is carried out by way of lease or utilization cooperation. Paragraph (2) stated that the land referred in paragraph (1) must prove to have been registered with a certificate of land rights in accordance with statutory provisions. In Paragraph (3), the execution of leasing or utilization cooperation as referred in paragraph (1) shall be carried out in accordance with statutory regulations.

Article 20 paragraph (1) provided that the utilization of waqf land for the construction of flat as referred to in Article 18 letter b shall be carried out by way of lease or utilization cooperation according to the endowment pledge. As in Paragraph (2), if the use of waqf land as referred to in paragraph (1) is not in accordance with the endowment pledge, the designation may be changed after obtaining approval and/or written permission from the Indonesian Waqf Board in accordance with the provisions of the legislation. Further regulated in Paragraph (3), the change of the designation 
as intended in paragraph (2) can only be done for the construction of public flats. In Paragraph (4) gives condition that the implementation of lease or utilization cooperation as referred to in paragraph (1) is carried out in accordance with sharia principles and legislation. At last, Paragraph (5) states that further provisions concerning the utilization of waqf land for public flats are regulated by government regulations.

Based on the description above, using the normative research method, the question being asked is whether the legal status of flat unit ownership specified in Law Number 20 of 2011 conflict with article 16 of Law No. 5 of 1960 or not?

\section{Research Method}

The type of research chosen is normative legal research or doctrinal legal research, namely legal research that conceptualizes law as the norm (Wignyosoebroto, 2002), because this research is normative legal research, so as to solve or answer the proposed problems (legal issues), conceptual approach, case approach and historical approach are used (Marzuki, 2011). The legal material from normative research can be divided into three namely,

1. Primary legal material, is the main legal material in this study, consists of laws and regulations relating to land.

2. Secondary legal law, includes library materials that provide explanations about primary legal materials 31 such as books, works from the legal community, literature, magazines, newspapers, electronic media as well as other data references relating to the issue of compensation for land acquisition for development in the public interest (Hermansyah, 2009).

The technique of searching primary and secondary legal materials is done by studying literature and internet searching (Rahardjo, 2000). The processing of legal materials is carried out by systematizing written legal materials. Analysis of the materials that have been collected must be done according to methods of analysis or interpretation (interpretation) of known law, such as authentic interpretation, interpretation according to grammar (grammatical), interpretation based on the history of the law (historical wets) or based on the history of law (historical rechtshistoris), systematic interpretation, sociological interpretation, theological interpretation, functional interpretation or futuristic interpretation (as an estimate). Of the several ways of analysis or interpretation (interpretation) the authors choose analysis using systematic interpretation, grammatical (grammatical), teleological interpretation (Abdlatif \& Ali, 2010).

\section{Results and Discussion}

Flat Unit Ownership Rights (FUOR) is a new rights institution which introduced through the Law on Flats (LoF). According to the LoF, FUOR is individual and separated. In addition to ownership of flats unit, FUOR also includes joint ownership rights called "shared parts", "shared land", and "shared objects", which all constituting an integral part of flats unit; since the ownership of flats unit includes the shared land, the flats unit can only be owned by an individual/legal entity who meet the requirements of holding the shared land rights.

Article 46 of Law Number 20 Year 2011 stipulates:

(1). Flat Unit Ownership Rights is an ownership rights to an individual flats unit which separated from the shared rights over the shared parts, shared objects, and shared land.

(2). The right to shared unit and shared land as referred to in paragraph (1) shall be calculated based on the Proportional Comparison Value (PCV).

Shared parts are the parts of a flat block which owned separately for shared use in one unitary function. For example: columns, stairs, roof, in-out access of the flats, public rooms, foundations and so on. The shared parts cannot be used by the owner of flat unit because it is a joint right of all the flat unit owners. Shared land is a piece of land that used on the basis of separate joint rights on which flats are built and the boundaries of the building are determined with the permit conditions. Article 17 of LoF determines that flats can only be built on rights of ownership, rights to build or utilize on state's land, and rights to build or utilize on land with management rights. The rights to shared land determine whether or not a person/legal entity to possess a flat unit. Shared objects are objects that not part of the flat but are shared and inseparable for shared use, for example: parks, sports and recreation facilities, fire extinguishers, clean water networks, electricity, gas, telephones, sewerage, drain, garbage bin, elevator/escalator, and others. According to Imam Kuswahyono (2004), the ownership system for multi-story building units is divided into 2 (two):

\section{Single ownership}

2. Multi ownership

Single ownership can be seen from the ownership of the land where the high rise building stands, so that the certificate holder is also the owner of the building. The shared ownership system is divided into two, by looking at whether or not there is a legal 
binding that previously exists between high rise buildings, as follows:

1. Bound Joint Ownership, the main basis is the existence of legal binding between the owners. The rules are based on the Regulation of the Minister of Internal Affairs Number 14 of 1975.

2. Free Joint Ownership, i.e. between owners there is no prior legal relationship other than the joint rights to be the owner for shared utilizations. The basic rule is the LoF jo. Government Regulation No. 4 of 1988 concerning Flats. This free joint ownership system is known as condominium.

Referring to the above description, land ownership rights on a flats unit in the perspective of law on objects refers to condominium system as regulated in book II of the Civil Code, where individual owners of a Flats unit are the occupants' rights. Beside that, there are common ownership rights over the land where the building is located (common areas) and common property rights over the building facilities (common elements).

In Article 6 and Article 77 of the Government Regulation No. 4 of 1988 concerning Flats, it is stipulated: Flat units can be on the surface of the land, above the ground, below the surface of the land, partly below and partly above the ground level. Flat units must have a direct connection to the exit or have access to public roads. In Article 47 of Law No. 20 of 2011 concerning Flats:

(1). Proofs of flat unit ownership on land with rights of ownership, rights to build or utilize on state's land, or rights to build or utilize on land with management rights, are issued in form of certificates of Flat Unit Ownership Rights (FUOR).

(2). FUOR as referred to in paragraph (1) is issued to every person who qualifies as a holder of land rights.

(3). FUOR as referred to in paragraph (1) constitutes an inseparable unit consisting of:

a. A copy of land book and the measurement letter on the shared land in accordance with statutory regulations;

b. Draw on the floor plan at the level of the related flats which shows the owned flat unit;

c. Explanation regarding the portion of the right on the shared parts, shared objects, and shared land for the person concerned.

(4). FUOR as referred to in paragraph (1) shall be issued by the district/municipal land registration office.

(5). FUOR can be used as collateral for a loan by being burdened with mortgages according to the provisions of the legislation.
When compared with other countries abroad, according to Arie $\mathrm{S}$. Hutagalung (2003), the term "strata title" is more likely to have horizontal joint ownership in addition to vertical ownership. Furthermore, according to Maria SW Sumardjono (2008), strata title is a system that allows the distribution of land and buildings in units called parcels, each of which is a separate right. In addition to individual ownership, it is also known the terms land, objects, and parts, which are common property. In the Housing and Settlement Law, common property is referred as social and public facilities. Based on the Regulation of the Minister of Internal Affair No. 1 of 1987 concerning the Submission of Environmental Infrastructure, Public Facilities, and Social Housing facilities to local governments, the composition is $60 \%$ (buildings): $40 \%$ (social facilities and public facilities). The concept of strata title can be applied to buildings such as highrise, residential, town houses, factories, offices and retail. According to Djuhaendah Hasan (2008), in several countries including Australia, New Zealand, Singapore, Malaysia and Hong Kong, the problem of providing land ownership for horizontal housing construction was replaced with vertical housing construction using the strata title system, that is a system that regulates the portion of land consisting of layers (strata), namely: the lower and upper layers. Strata is a plural form of stratum which is defined as the following: "stratum means any part of land consisting of a space of any shape below on or above the surface of the land, dimensions of which are delineated".

In order to guarantee legal certainty and legal order in the matter of someone's ownership, it must be within the legal framework of property. One's ownership on a flat unit must have proof on its land rights. According to Arie S. Hutagalung (2003), as proof of ownership rights to a flat unit, a powerful evidential tool is provided in the form of a certificate of ownership rights over the flat units. The form and procedure for the registration of land books and the issuance of FUOR certificates are regulated in the Regulation of the Head of National Land Agency No. 4 of 1989. The administration of FUOR and the issuance of certificates are based on the information/data contained in the deed of the split which has been approved by the regional government. Government Regulation No. 4 Year 1988 concerning Flats establishes that FUOR is one of the products of a series of licensing processes in the flat system that highly dependent on the previous/upstream licensing products, including Location Permits and Building Construction Permits (IMB). The licensing sequence to the certification process must include, among others: location permit, land acquisition, building permit, ratification, livable permit, ratification of the deed of the split for the flats into flat units, registration of the deed of split, and issuance of the FUOR certificate. 
The certificate is a proof that acts as a strong evident of the physical data and juridical data contained therein, as long as the physical data and the juridical data are in accordance with the data contained in the measuring certificate and land book of the relevant rights. For flats that stand on leased land which status is the state's land, or an endowments/waqf land, it will issue a Certificate of Building Ownership (SKBG). Unlike the land title certificate, the FUOR certificate and the SKBG which used as collateral will be encumbered with the Mortgage Right, instead of the land. Therefore, the security rights imposed in the FUOR and SKBG are the status of ownership on which the shared parts, the shared objects, and the shared land.

Based on Article 16 of Law Number 5 of 1960 concerning Basic Agrarian Principles, the types of existing rights are: rights of ownership, rights to function, rights to utilize, rights to use, rights to lease, rights for land opening, and rights to collect forest products. Other rights not included above will be determined by law (Setiawan, 2010).

\section{Conclusions}

Based on the above description, Law Number 16 of 1985 concerning Flats has been replaced by Law Number 20 of 2011 concerning Flats; it cannot be said that there is conflict of norms between Law Number 5 of 1960 on Basic Agrarian Principles in Article 16, and Law Number 20 of 2011 concerning Flats. The difference in interpretation of the above law can be resolved by, first: the principle of lex specialis derogate lex generale, means specific laws (in this case is Law Number 20 of 2011 concerning Flats) overriding the general laws (in this case is the Law Number 5 of 1960 on Basic Agrarian Principles); secondly: Article 16 Paragraph (1) letter h of Law Number 5 of 1960 concerning Basic Agrarian Principles provided: other rights not included in the rights mentioned above will be determined by the law, as well as the temporary rights mentioned in article 53; thus the term certificate of ownership over a flat unit is accepted because it does not conflict with applicable laws and regulations.

\section{References}

1. Abdlatif and Hasbi Ali. (2010). Perihal Kaedah Hukum. Bandung: Citra Aditya Bakti.

2. Hasan, D. (2008). Fungsi Hukum dalam Perkembangan Ekonomi Global. Bandung, Faculty of Law Padjajaran University.

3. Hermansyah, N. (2009). Metodologi Penelitian dan Penulisan Hukum, Banjarmasin, STIH-SA Press.

4. Hutagalung, A.S. (2003). Condominium dan Permasalahannya. Third Print. Depok, The Agency of Publishing Faculty of Law Indonesia University.
5. Ibrahim, J. (2006). Teori \& Metodologi Penelitian Hukum Normatif, Malang: Penerbit Bayumedia Publishing. 6. Kuswahyono, I. (2004). Hukum Rumah Susun. Malang, Bayumedia Publishing.

7. Marzuki,P.M. (2011). Penelitian Hukum, Jakarta: Kencana Prenada Media Group.

8. Rahadjo, S. (2000). Ilmu Hukum. Bandung: Citra Aditya Bhakti.

9. Setiawan, Y. (2010). Hukum Pertanahan dan Praktik. Malang, Banyumedia Publishing.

10. Soekanto, S. dan Mamudji, S. (2004). Penelitian Hukum Normatif, Jakarta: Cetakan ke-8 PT. Raja Grafindo Persada.

11. Sumardjono, M.S.W. (2008). Tanah dalam Perspektif Hak Ekonomi, Sosial, dan Budaya. Jakarta, Kompas.

12. Wignyosoebroto, S. (2002). Metodologi Penelitian Hukum; Keragaman dalam konsep Tipe Kajian dan Metode Penelitiannya, Surabaya, Universitas Airlangga. 